\title{
Percepatan Daya Usaha Industri Olahan Buah Salak Melalui Rekonstruksi Technopreneurship
}

\author{
Didik Suharijadi, Suharto, Mochamad Ilham \\ Faculty of Humanities, Universitas Jember \\ Didiksuharijadi.sastra@unej.ac.id
}

\begin{abstract}
Abstrak
Masyarakat Desa Pancakarya Kecamatan Ajung memanfaatkan hasil pertanian yang berlimpah dengan membangun home industry yang mengolah hasil pertanian menjadi keripik dan kopi. Salah satu hasil pertanian yang diolah adalah buah dan biji salak. Hasil olahan mereka menambah keanekaragaman kuliner Kabupaten Jember. Dari hasil analisis diperoleh garis besar permasalahan utama yang dihadapi oleh mitra yaitu area pemasaran yang sempit. Kondisi ini menyebabkan perekonomian mitra tidak dapat optimal. Program pengabdian bertujuan mengupayakan tumbuhnya kreatifitas varian produk, dan pengadaan alat proses produksi yang dapat meningkatkan jumlah dan standar produk olahan buah salak, serta pola pemasaran yang lebih global. Oleh karena itu, target khusus dari program ini adalah mitra memiliki barang produksi yang lebih terstandart berbasis teknologi terapan dan pola pemasaran yang berbasis sistem informasi. Tim pengusul kegiatan pengabdian kepada masyarakat berusaha memberikan solusi dengan membantu pengadaan peralatan produksi olahan buah salak. Untuk merealisaikan tujuan program dan mendapatkan target yang diinginkan, maka dilakukan pelatihan pengetahuan mengenai technopreneurship. Pada program pengabdian ini akan banyak diketengahkan kegunaan teknologi dan manfaatnya untuk mendukung pembuatan olahan buah salak yang memiliki rasa yang khas, terstandard sehingga dapat dipercaya oleh konsumen. Pada mitra juga akan dilatih untuk menjual produk luaran pengabdian dengan pola pemasaran secara online maupun offline. Pemasaran secara online selain meningkatkan penjualan produk juga menjadi ajang promosi kekhasan Jember. Pemasaran offline sasarannya adalah toko-toko dan pasar, baik pasar tradisional maupun pasar modern
\end{abstract}

Kata Kunci: Olahan salak, kuliner Jember, pemasaran online, kekhasan Jember

\begin{abstract}
Community of Pancakarya Village, Ajung Sub-district utilizes abundant agricultural products by building a home industry that processes agricultural products into chips and coffee. One of the agricultural products that is processed is fruit and bark seeds. Their processed products add to the culinary diversity of Jember Regency. From the results of the analysis obtained an outline of the main problems faced by partners is a narrow marketing area. This condition causes the partner economy to not be optimal. The service program aims to strive for the growth of product variant creativity, and the procurement of production process tools that can increase the number and standards of processed zalacca products, as well as more global marketing patterns. Therefore, the specific target of this program is that partners have more standardized production goods based on applied technology and marketing systems based on information systems. The team proposing community service activities tried to provide a solution by helping to procure processed salak fruit production equipment. To realize the objectives of the program and get the desired target, then a knowledge training on technopreneurship is conducted. In this service program, there will be a lot of information on the usefulness of technology and its benefits to support the making of processed snake fruit which has a distinctive, standardized taste so that it can be trusted by consumers. Partners will also be trained to sell service products with marketing patterns online and offline. Online marketing in addition to increasing product sales is also a promotional event for Jember's specialty. The offline marketing target is shops and markets, both traditional markets and modern markets
\end{abstract}


Keywords: Processed with salak, culinary of Jember, online marketing, peculiarity of Jember

\section{PENDAHULUAN}

Kabupaten Jember sebagai daerah yang memiliki kondisi wilayah agraris dengan kultur pertanian dan perkebunan merupakan sebuah potensi sumberdaya alam yang melimpah untuk ditumbuh kembangkan. Upaya-upaya perlu dilakukan untuk menambah penghasilan masyarakat pedesaan, khususnya di tingkat petani. Komoditas unggulan di daerah agraris meliputi buah-buah-buahan dan kacang-kacangan. Salah satu komoditas perkebunan yang terdapat di wilayah Jember yang berpotensi untuk dikembangkan adalah buah salak. Buah ini banyak dihasilkan di daerah Semboro yang merupakan sentra perkebunan jeruk dan salak. Komoditas salak di Semboro Kabupaten Jember dapat menghasilkan produksi yang cukup besar.

Pola mata pencaharian masyarakat di sektor pertanian dan perkebunan dipengaruhi oleh kondisi geografis alam sekitarnya. Hal ini dapat terlihat dari multiplier effect keberagaman pemanfaatan komoditas yang dihasilkan dari sumber daya alam. Hasil dari sumberdaya alam perkebunan dalam hal ini berupa buah salak dan sejenisnya tergolong dalam perishable produk, artinya hasil dari perkebunan buah salak memiliki masa penyimpanan yang singkat dan mudah membusuk. Untuk mengatasi agar komoditas yang dihasilkan dapat membawa keuntungan maka diperlukan upaya untuk melakukan pengolahan hasil perkebunan tersebut dengan melakukan pembuatan diversifikasi dari buah salak. Beberapa diversifikasi Olahan Buah Salak adalah kurma salak, dodol salak dan keripik salak. Pengolahan salak menjadi aneka olahan makanan tersebut merupakan usaha alternatif dari hasil perkebunan sebagai nilai tambah bagi masyarakat di wilayah pertanian dan perkebunan.

Desa Pancakarya merupakan desa yang masyarakatnya memberdayakan hasil-hasil pertanian dan perkebunan untuk diolah menjadi sesuatu yang memiliki nilai jual yang tinggi. Salah satunya adalah Muhammad Bustomy (28 tahun). Bustomi memiliki ide memberdayakan hasil-hasil perkebunan yang terdapat di daerah Semboro. Idenya berawal dari melihat buah salak dalam jumlah besar yang dihasilkan oleh daerahnya. Buah yang berlimpah tersebut hanya dapat bertahan dalam jangka waktu yang tidak lama. Bustomi kemudian mencoba untuk mengolah buah salak untuk dikonsumsi sendiri.

Pada musim panen salak harga jual salak sangat rendah. Hal ini disebabkan jumlah ketersediaan buah salak melimpah. Untuk itu Bustomi mencoba melakukan pengolahan buahbuah salak menjadi berbagai makanan yang memiliki nilai jual yang tinggi. Hasil pengolahan dari buah salak diantaranya kurma salak, keripik salak dan dodol salak. PengOlahan Buah Salak dari proses awal sampai akhirnya menjadi aneka olahan makanan dilakukan dengan menggunakan cara konvensional dan tradisional, sehingga produk-produk yang dihasilkan masih dalam skala IRT atau home industry. Kualitas produk hasil olahan Bustomi awalnya belum dapat dipasarkan ke ranah yang lebih luas. Proses produksi pengOlahan Buah Salak masih mengandalkan cara-cara yang sederhana mulai dari penggorengan hingga penirisan. Pembuatan kurma salak dan dodol salak juga masih mengandalkan peralatan tradisional.

Pola pemasaran yang dilakukan oleh Bustomi masih mengandalkan permintaan dari pasar lokal dan penjualan secara langsung melalui penawaran dari satu orang ke orang lain. Bustomi sebagai pelaku usaha buah salak masih memerlukan pengetahuan dan pembelajaran mengenai teknik-teknik dan sistem manajemen yang baik untuk diterapkan di home industri. Utuk itu, dibutuhkan pelatihan dan penyuluhan agar memiliki pengetahuan dan ketrampilan yang memadai agar dapat membedakan kualitas olahan yang bermutu tinggi dan yang bermutu rendah. Kompetensi-kompetensi yang disebut di atas diharapkan menjadi modal dasar untuk memproduksi Olahan Buah Salak yang baik. Ketekunan dan keuletan untuk belajar lebih baik lagi merupakan kunci utama untuk peningkatan usaha diversifikasi buah salak. Mutu produk yang baik dapat menjadikan komoditas yang layak didistribusikan di pasar global. Diperlukan berbagai pengetahuan dan pengalaman dari praktisi maupun akademisi agar diperoleh kualitas dan citarasa yang prima sehingga dapat bersaing dengan hasil-hasil olahan sejenis dari kawasan lain. 
Peluang peningkatan proses produksi dan pemasaran industri rumah tangga Olahan Buah Salak merupakan upaya percepatan yang tidak bisa diabaikan atau ditunda-tunda lagi. Hal ini disebabkan produksi hasil olahan perkebunan yang khas pada suatu wilayah dipengaruhi oleh kekhasan hasil sumberdaya alam di wilayah perkebunan. Ragam jenis buah salak memiliki kesamaan dengan beberapa jenis buah salak yang lain di Indonesia, akan tetapi keberagaman dan keadaan klimatologi serta geografi di sebuah daerah perkebunan memiliki keunikan dan citarasa yang berbeda. Perkebunan di Jember merupakan perkebunan yang menghasilkan berbagai komoditas unggulan yang sudah terkenal di masyarakat Indonesia salah satunya kopi dan kakao begitu juga buah salak yang memiliki citarasa yang khas dan unik. Keunikan dan kekhasan tersebut menjadi modal dasar bagi masyarakat sekitar untuk memberikan dan menunjukkan upaya pengolahan hasil disamping produk melalui hasil Olahan Buah Salak. Oleh karena itu pola perdagangan hasil perkebunan dari yang sederhana akan dikembangkan melalui proses produksi dan pemasaran melalui sistem informasi. Teknologi diterapkan dalam pengolahan, dan sistem informasi diterapkan dalam pemasaran. Dengan melibatkan teknologi dan sistem informasi diharapkan mampu melakukan percepatan proses produksi dan pemasaran sehingga hasil Olahan Buah Salak dapat menjadi komoditas unggulan Kabupaten Jember.

\section{METODE PELAKSANAAN}

Metode pelaksanaan yang dilakukan dalam pengabdian ini adalah mengintegrasikan keseluruhan kegiatan yang dilakukan dengan unsur-unsur pengetahuan manajeman produksi barang dagangan dan pengetahuan tentang teknologi alat produksi untuk penggorengan, penirisan, pengovenan dan pengaduk buah salak. Selain itu, dilakukan sosialisasi metode pola pemasaran barang dagangan secara offline dan secara online. Rangkaian kegiatan itu dilakukan sebagai usaha untuk membangkitkan gairah berwirausaha bagi mitra yang melaksanakan program ini. Secara rinci kegiatankegiatan yang dilakukan diuraikan sebagai berikut :

\section{A. Deskripsi Kegiatan}

Pihak mitra merupakan pelaku bidang usaha kecil yang telah memulai usaha dari nol dan berkecimpung dalam bidang kuliner khas Jember, akan tetapi minimnya pengetahuan dan kreatifitas dalam menjalankan usaha kecilnya secara komprehensif dan hanya berbekal pengalaman usaha yang dijalani berjalan keadaan yang stagnan dan tidak optimal sehingga berdampak pada kurangnya kreatifitas dalam pola pemasarannya. Berdasarkan analisis permasalahan yang telah diuraikan pada bab sebelumnya, maka tahapan -tahapan kegiatan yang akan dilaksanakan dalam program ini adalah sebagai berikut :

1) Sosialisasi bentuk program yang ditawarkan

2) Pelatihan pengetahuan technopreneurship dalam memanfaatkan buah salak

3) Peningkatan Produksi dan Penjualan Olahan Buah Salak

4) Pembuatan proses produksi dengan sarana teknologi terapan pada proses penggorengan, penirisan, pengovenan dan pengadukan buah salak

5) Pendampingan proses produksi dan pola pemasaran dan dalam penggunaan media online.

6) Evaluasi hasil kegiatan

\section{HASIL DAN PEMBAHASAN}

Kegiatan pengabdian masayarakat diawali dengan sambutan dari ketua kegiatan yaitu Didik Suharijadi. Dalam sambutannya ketua pengabdian menyampaikan mengenai maksud dan tujuan diadakan kegiatan Peningkatan Daya Usaha Industri Alahan Buah 
Salak. Pada intinya ketua menyampaikan bahwa kegiatan ini diharapkan mampu untuk menghasilkan produk Olahan Buah Salak yang berkualitas dan mampu bersaing dengan produk-produk yang sejenis yang sudah dipasaran dan dapat meningkatkan perekonomian IRT Koplak Food. Selain itu jugadisampaikan pentingnya pola pemasaran/promosi memanfaatkan teknologi audio visual dan teknologi online melalui internet. Dengan program pengabdian tersebut diharapkan IRT Koplak Food mampu menghasilkan Olahan Buah Salak yang secara rasa gurih, renyah dan disukai masyarakat sehingga dapat menjadi oleh-oleh khas dari Kota Jember.

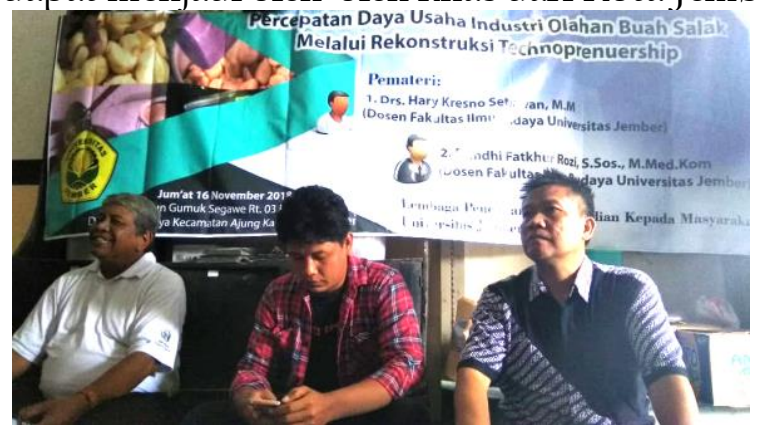

Gambar l. Pembukaan Acara Pelatihan oleh Ketua Kegiatan (Dokumen Pribadi)

Kegiatan dilanjutkan dengan sesi berikutnya yaitu materi mengenai manajemen pemasaran yang disampaikan oleh Drs, Hary Kresna, M.M. Pemateri menyampaikan materi mengenai pentingnya produk dan pemasaran harus dilakukan dengan cara bersamaan dan tidak boleh terpisahkan kedua prosesn tersebut. Dijelaskan bahwa kegiatan memproduksi sebuah barang dalam hal ini olahan buah salak juga diimbangi dengan memasarkan produk tersebut, dengan tujuan supaya produk yang dihasilkan dapat dikenal dan tersebar luas di kalangan masyarakat.

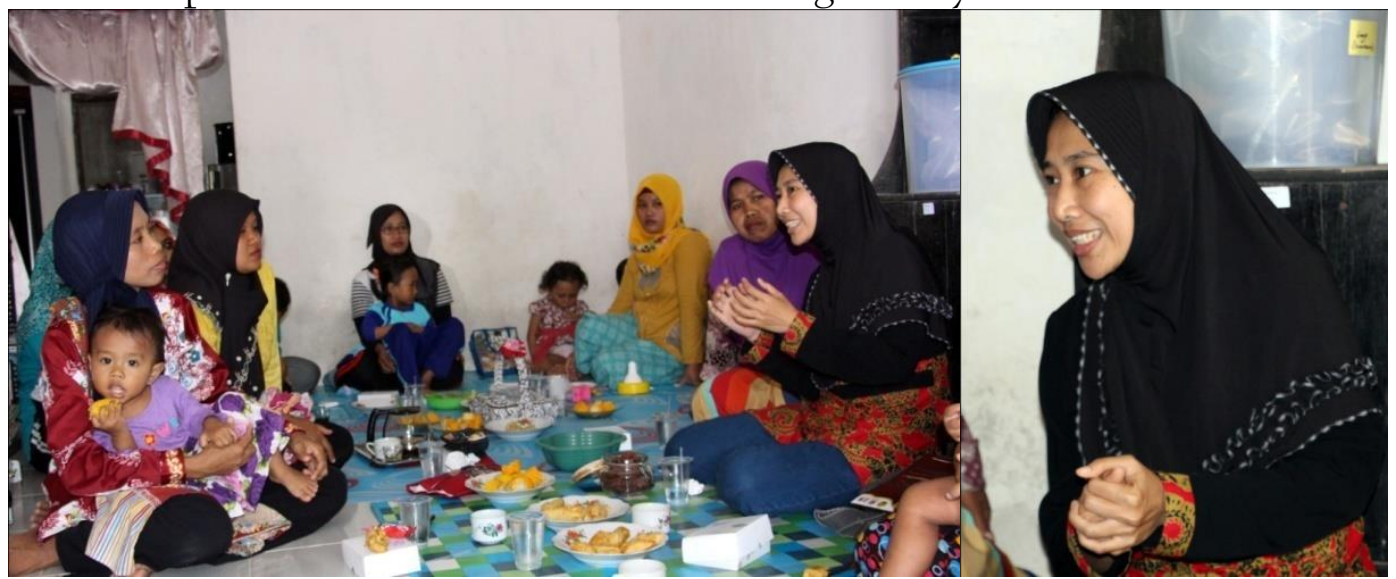

Gambar 2. Penyampaian materi manajemen pemasaran (Dokumen Pribadi)

Pemateri Romdhi Fatkhur Rozi, S.Sn., M.Sn. yang menjelaskan perihal segmentasi pasar. Tujuan segmentasi pasar adalah untuk menetapkan khalayak yang menjadi calon pembelin (jenis, kelamin, usia, profesi), di mana daerah pemasarannya. Penentuan target pemasaran menjadi sesuatu yang harus dipikirkan di awal karena dengan segmentasi pembeli produk dan daerah pemasaran yang telah ditentukan maka pemasaran produk yang berupa Olahan Buah Salak dapat memenuhi target yang direncanakan. Pemateri juga menyampaikan pentingnya managemen pemasaran baik manajemen pemasaran tradisional maupun modern. Menurut Kotler (2003), saat ini terdapat dua jenis pemasaran, pemasaran tradisional dan pemasaran modern. 
Pemasaran modern telah mengambil alih pemasaran tradisional karena menekankan pada konsep pengalaman pelanggan dan experiential marketing. Kotler (2003) juga menyebutkan bahwa saat ini semakin banyak merek atau perusahaan yang mengembangkan citra non rasional ini. Mereka meminta masukan dari psikolog dan antropolog untuk membuat dan memperbaiki pesan untuk membuat sentuhan jiwa yang mendalam bagi konsumen. Holbrook (2000) percaya bahwa ketika pasar memasuki periode pemasaran pengalaman, fokus utama akan berubah dari kinerja produk untuk pengalaman hiburan. Dengan kata lain, perbedaan utama antara pemasaran tradisional dan pemasaran modern terletak pada fokusnya. Bila pemasaran tadisional tradional berfokus pada fitur produk dan benefitnya, pemasaran modern berfokus pada pengalaman pelanggan secara menyeluruh.

Kedua jenis pemasaran tersebut juga memiliki cakupan yang berbeda. Pemasaran tradisional cakupannya sempit karena berfokus pada produk dan konsumsi, pemasaran modern menekankan pada situasi dan suasana mengkonsumsi secara lebih luas dalam konteks sosial budaya. Ini karena pemasar modern melihat bahwa model keputusan pembelian konsumen sekarang lebih bersifat emosial - dala arti mempertimbangkan masalah perasaan, fun, dan fantasi - ketimbang rasional. Inilah yang membuat pendekatan pemasarannya menjadi berbeda. Bila dalam pemasaran tradisional pendekatannya lebih pada hal-hal yang bersifat analitis, verbal dan kuantitatif, maka pendekatan pemasaran modern lebih pada hal-hal yang sifatnya visual intuitif meski tetap memperhatikan hal-hal yang verbal dan elektik. Pemasaran secara modern menggunakan teknologi yang serba canggih seperti sekarang yaitu internet. Melalui internet jangkauan yang luas dan lebih praktis memesan barang atau bertransaksi. Dengan peningkatan pemakaian internet dan jumlah ponsel yang dilengkapi fasilitas internet yang menawarkan berbagai fitur online dengan cara kita duduk dan mengklik saja kita sudah dapat memilih barang ataupun membeli barang secara online.

Dengan memanfaatkan internet pelanggan tidak perlu menghadapi atau melayani bujukan. Selain itu pemasaran online juga menjajikan efektifitas. Pemasaran online memungkinkan tersebarnya informasi secara luas dan dapa diakses 24 jam. Secara sederhana dapat disimpulkan bahwa pemasaran tidak terkendala oleh ruang dan waktu. Selain efektifitas, pemasaran online juga berdampak efisinensi. Efisiensi dapat membuat konsumen mengeluarkan biaya yang rendah. Pemasaran online juga membuat interaksi bisnis lebih konkrit. Kesepakatan segera menjadi konkrit dan terealisasi. Kelebihan-kelebihan pemasaran secara modern inilah yang menyebabkan pola pemasaran ini menjadi sarana utama bagi produk luaran pengabdian ini.

Pemaparan materi oleh Romdhi Fatkhur Rozi, S.Sn., M.Sn diikuti dengan penuh antusias oleh para peserta yang mayoritas ibu-ibu rumah tangga di Desa Pancakarya Ajung Jember. Hal ini terbukti dengan beberapa pertanyaan yang dilontarkan oleh peserta terkait dengan pola-pola promosi di zaman yang serba canggih seperti sekarang ini. Begitu juga dengan mengenai manajemen pemasaran mulai dari perencanaan hingga evaluasi.

Kegiatan sesi II adalah penyampaian materi tentang pemasaran produk melalui terknologi audio dan internet oleh Romdhi Fatkhur Rozi, S.Sos. M.Med. Kom. Didalam pemaparannya pemateri menyampaikan mengenai media-media apa saja yang dapat digunakan para produsen makanan untuk untuk memperkenalkan produk kepada masyarakat. 


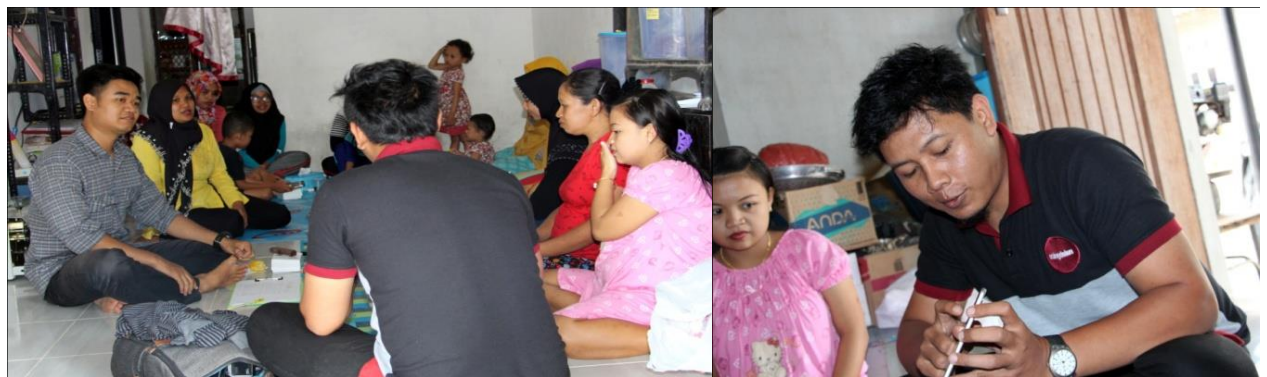

Gambar 3. Penyampaian materi company profile dan pembuatan blog (Dokumen Pribadi)

Pelatihan Pembuatan Blog yang disampaikan oleh Romdhi Fatkhur Rozi, S.Sos. M.Med. Kom Log atau yang sering juga disebut blog adalah sebuah diary atau catatan-catatan pribadi yang disimpan secara online dan umumnya bersifat terbuka bagi siapa saja yang ingin membacanya. bisa juga berisi kutipan dari sumber lain yang sengaja dipublikasikan kembali dalam satu tempat. Blog juga sama dengan situs-situs atau web yang sering anda temui di internet. Materi dan konten merupakan kebebasan penuh dari sang pembuat blog. tentu saja sangat disarankan lebih ke arah membagi pengetahuan yang bermanfaat.

Fungsi dan kegunaan sebuah blog dengan memiliki blog, diharapkan para pelaku industri rumah tangga dapat melatih kemampuan dalam menyampaikan suatu informasi atau hal-hal yang ingin kita sampaikan kepada orang lain dengan tanpa bermaksud menggurui tentang apa yang kita ketahui kepada masyarakat pada umumnya. Dengan mempunyai blog, para para produsen makanan dapat memperoleh banyak ide yang didapat dari berbagai sumber yang memberikan komentar atas tulisan yang kita terbitkan di blog yang kita buat dan akan menjadi pacuan semangat kita dalam menggali pola pikir yang kreatif untuk mendukung pemasaran yang akan dilakukan dan bermanfaat bagi diri sendiri maupun bagi industri rumah tangga. Sudah banyak orang-orang yang meraih kesuksesan hanya dengan memiliki sebuah blog, karena blog bersifat terbuka bagi siapa saja sehingga dapat juga dijadikan sebagai sarana untuk mempromosikan produk olahan buah salak secara online diantara sela-sela karya tulisan yang mereka terbitkan dan disukai banyak orang yang mencari dan membacanya. Dengan blog dapat memiliki banyak teman dari berbagai daerah dan negara yang terdapat kesamaan kaitannya dengan isi blog yang dibuat. Belakangan ini, fungsi sebuah blog tidak hanya sebagai sarana membagi informasi dan kutipan yang sifatnya umum, namun lebih cenderung sebagai sarana promosi penjualan atas sebuah produk kesenian. Diera teknologi yang semakin berkembang muncul bermacam blogyang mengedepankan konten kurang mendidik, ataupun konten-konten dewasa yang berpotensi memperburuk pola pikir daripada aspek mendidiknya. Kecanggihan teknologi saat ini seharusnya mampu menjembatani keterbatasan pengetahuan bermanfaat antar sesama, jadi gunakanlah secara bijak. Blog dalam hal ini dapat digunakan untuk mempromosikan produk olahan buah salak kepada masyarakat luas sehingga masyarakat akan mengenal kesenian ini secara luas.

Materi II tentang pembuatan karya audio visual berupa company profile oleh Romdhi Fatkhur Rozi, S.Sos. M.Med. Kom. Didalam pemaparannya pemateri menyampaikan mengenai jenis-jenis profil yang dapat digunakan untuk mempekenalkan orang maupun produk kepada masyarakat.

Materi yang disampaikan oleh Romdhi Fatkhur Rozi, S.Sos. M.Med.Kom.mengemukakan bahwa ada prinsip-prinsip yang harus dimiliki oleh seseorang yang akan membuat sebuah company profile yang dapat menarik perhatian 
khalayak. Berdasarkan presentasi yang dilakukan oleh Romdhi, profil dari sebuah perusahaan akan menarik perhatian khalayak jika dapat memberikan pesan yang kuat kepada masyarakat, dimana masyarakat dapat menerima dan mengetahui maksud dan tujuan didirikannya sebuah perusahaan. Selain itu gambar yang menarik akan memperkuat profil sebuah perusahaan, karena sebuah gambar yang berkesan kuat akan menyampaikan informasi yang tepat dan akurat pada masyarakat yang melihat. Marketing mix juga menjadi salah satu pendukung bagi sebuah perusahaan untuk memiliki profil yang kuat. Marketing Fix yang terdiri dari unsur 7P (Product, Price, Promotion, Placement, People, Process, dan Physical Evidence) akan menjadi penentu bagi sebuah perusahaan untuk dipilih oleh masyarakat. Romdhi menjelaskan secara runtut mengenai 7P dimulai dari Product yang harus memiliki mutu dan kualitas yang unggul; Price yang lebih murah dibandingkan dengan pesaing lainnya; Promotion agar produk kita dikenal oleh khalayak; Placement yang berkaitan dengan distribusi produk kita ke dalam masyarakat; People yang berkaitan dengan sasaran penjualan produk kita; Process yang terdiri dari proses produksi dan proses pelayanan perusahaan terhadap konsumen; dan yang terakhir adalah Physical Evidence sebagai fasilitas pendukung atau sarana dalam menjual produk yang dapat dilihat langsung oleh konsumen.

Berdasarkan marketing mix di atas, perusahaan dapat mengidentifikasikan dirinya dengan para pesaing/kompetitor untuk kemudian menentukan dari faktor-faktor manakah dari ketujuh marketing mixtersebut, perusahaan memiliki keunggulan (Competitive Advantage) dibandingkan pesaing. Setelah perusahaan berhasil mengidentifikasikan posisinya maka angkatlah kelebihan tersebut sebagai selling point dalam company profile khususnya dari segi produk/servis.

Pada intinya tujuan dari pembuatan profile baik profil individu, perusahaan maupun instansi pemerintah yaitu untuk memperkenalkan mengenai seseorang atau produk sehingga masyarakat dapat memperoleh keterangan yang mendetail dari profile yang disampaikan tersebut.

Peralatan yang biasa digunakan untuk penggorengan pembuatan kripik salak untuk menghasilkan hasil yang sesuai dengan standar pasar dan standar kerenyahan kripik yaitu dengan menggunakan Mesin Vacuum Frying berfungsi sebagai mesin untuk menggoreng buah atau sayur menggunakan metode vacuum/sedot sehingga buah atau sayuran menjadi bentuk baru berupa kripik buah dan kripik sayur. Prosesnya yaitu dengan menurunkan tekanan pada tabung penggorengan, maka suhu didalamnya pun juga akan semakin turun. Dengan tekanan dibuat vacuum, maka suhu akan turun semakin jauh sehingga bisa dilakukan penggorengan pada suhu rendah. Dengan proses inilah kemudian bahan-bahan yang semestinya tidak bisa digoreng, akhirnya bisa di goreng juga dan menghasilkan produk baru. Mesin inilah yang diperbantukan untuk mitra agar dapat menghasilkan produk kripik salak yang gurih dan renyah. 


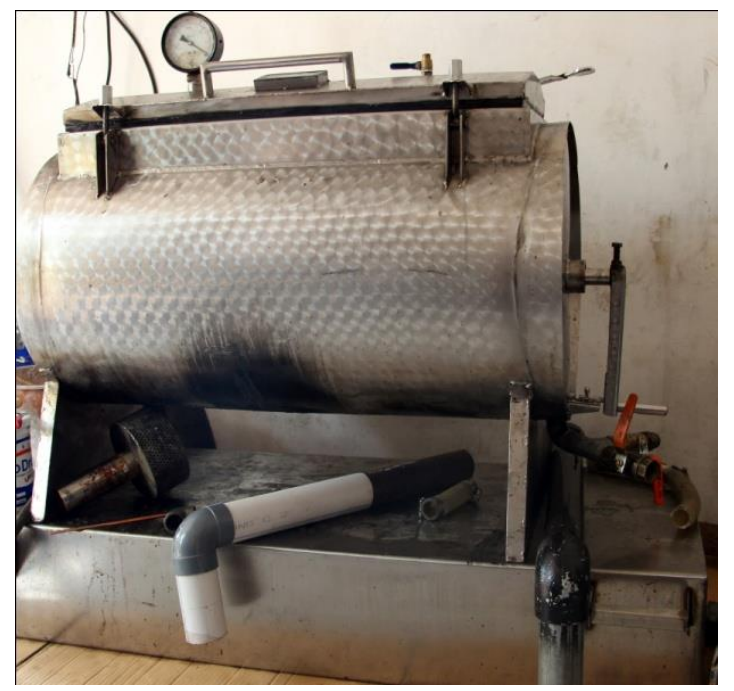

Gambar 4. Vacuum Frying atau peralatan penggorengan yang diberikan kepada mitra (Dokumen Pribadi)

Setelah proses penggorengan kemudian untuk mengatasi kandungan minyak berlebihan pada keripik yaitu menggunakan mesin peniris atau spinner yang berfungsi untuk mengurangi kadar minyak atau air pada makanan maupun keripik. Selain untuk mengurangi kandungan minyak, mesin ini juga dapat berfungsi untuk mengurangi kadar air pada produk tertentu. Misalnya bahan baku yang dicuci dan ingin cepat kering, maka dengan menggunakan mesin peniris minyak atau spinner, kandungan air bisa cepat kering. Mesin inilah yang diperbantukan untuk mitra agar dapat menghasilkan produk olahan buah salak yang kadar minyaknya hilang dan kering.

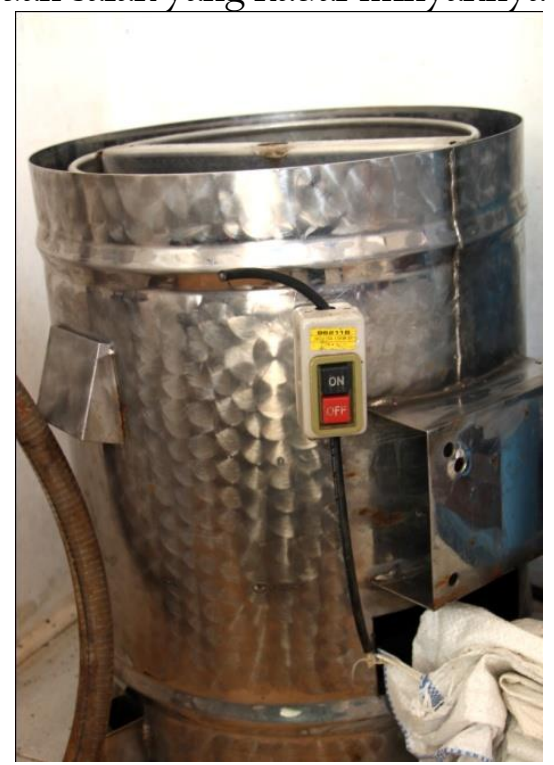

Gambar 5. Spinner atau peralatan peniris (pengering minyak)

(Dokumen Pribadi)

Sarana dan prasaran merupakan sebuah penunjang kelancaran sebuah produksi olahan buah salak, oleh karena itu untuk membuat produk yang berkualitas diperlukan peralatan yang canggih dan modern tujuannya agar produk-produk yang dihasilkan mampu bersaing dengan produk keripik lainnya dipasaran. 


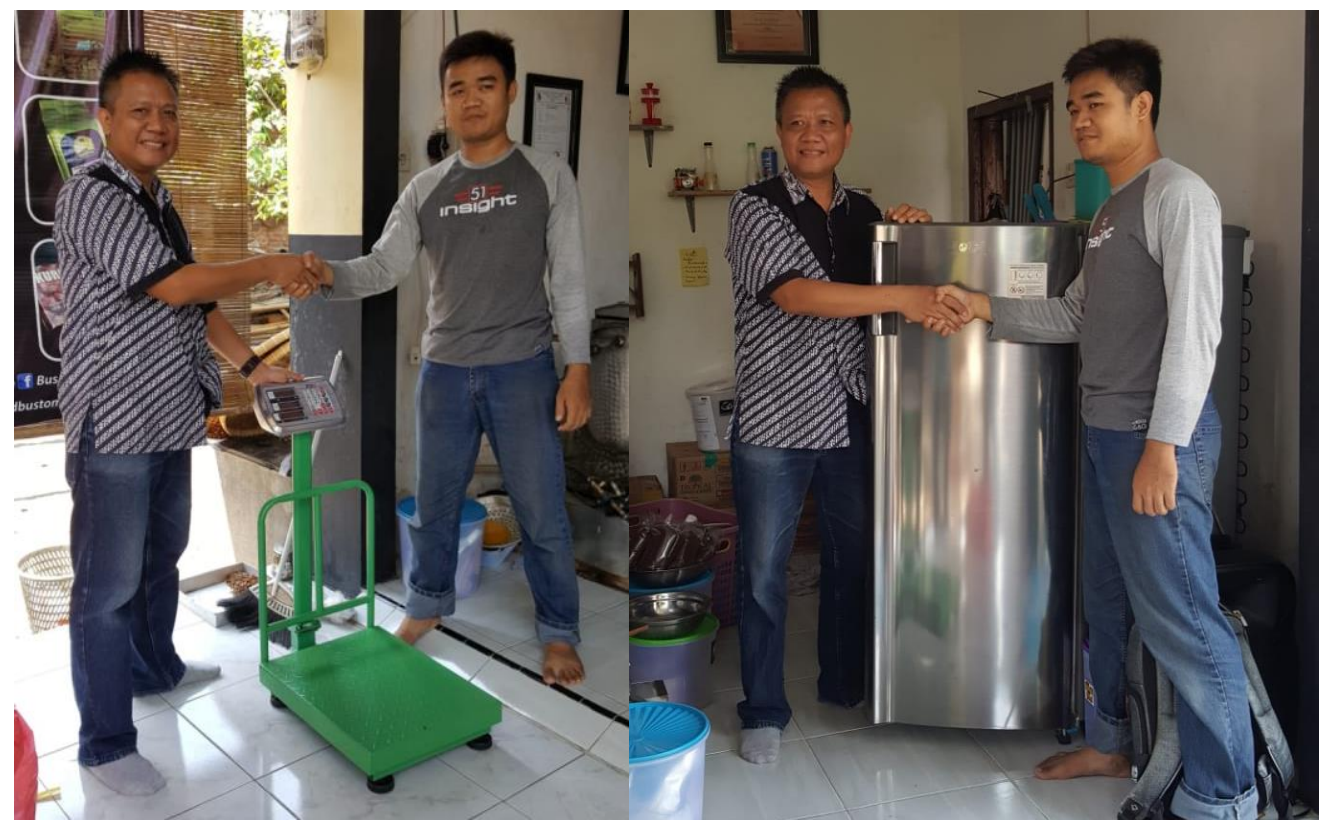

Gambar 6. Penyerahan peralatan kepada Pemilik Koplak Food (Dokumen Pribadi)

Proses penyerahan Vacuum Frying dan Spinner untuk olahan buah salak diserahkan langsung oleh Didik Suharijadi, S.S., M.A selaku ketua kegiatan pengabdian kepada masyarakat dan diterima langsung oleh Muhammad Bustomy selaku owner dari Koplak Food. Vacum Fryinng dan spinner merupakan sarana utama untuk membuat olahan buah salak. Diharapkan dengan bantuan peralatan dan pengetahuan dari segala bidang baik dari manajemen, sistem pemasaran dan sarana prasarana pendukungnya dapat menjadikan olahan buah salak yang dihasilkan dari IRT Koplak Food ini digemari dan dikenal oleh masyarakat luas.

\section{PENUTUP \\ A. Kesimpulan}

Kegiatan pengabdian kepada masyarakat skim teknologi tepat guna dengan judul "Peningkatan Daya Usaha Industri Olahan Buah Salak Melalui Technopreneurship" ini diharapkan dapat membantu permasalahan yang dihadapi mitra dapat segera teratasi dalam rangka meningkatkan pengetahuan dan ketrampilan mitra.

Beberapa kegiatan yang telah dilakukan adalah sebagai berikut:

1. Pelaksanaan kegiatan pelatihan "Peningkatan Daya Usaha Industri Olahan Buah Salak Melalui Technopreneurship" melalui sub pelatihan I peningkatan kualitas manajemen pemasaran.

2. Pelaksanaan kegiatan pelatihan "Peningkatan Daya Usaha Industri Olahan Buah Salak Melalui Technopreneurship" melalui sub pelatihan II mengenai pemasaran produk lewat media online.

3. Pelaksanaan kegiatan pelatihan "Peningkatan Daya Usaha Industri Olahan Buah Salak Melalui Technopreneurship" melalui sub pelatihan III peningkatan kualitas pemasaran produk melalui teknologi audio visual (company profile)

4. Pelaksanaan kegiatan pembenahan sarana dan prasarana peralatan produksi

5. Pelaksanaan kegiatan monitoring dan evaluasi 


\section{B. Saran}

Secara umum kegiatan Peningkatan Daya Usaha Industri Olahan Buah Salak Melalui Technopreneurship dapat berjalan lancar. Akan tetapi kedepannya perlu kegiatan yang merupakan kelanjutan dari kegiatan ini yaitu untuk membuat promosi dan daya tarik masyarakat diperlukan sebuah branding produk kedepan akan dilakukan pelatihan mengenai teknik-teknik membuat label dan desain olahan buah salak yang menarik. Mengenai perijinan atau usaha dagang harus mengurusi di Kementerian Perindustrian untuk mendapatkan label yang legal, sehingga menjadikan olahan buah salak hasil produk dari IRT Koplak Food ini dapat menembus pemasaran diseluruh wilayah Jember.

\section{DAFTAR PUSTAKA}

Belch, GE, 2003, Advertising and Promotion - an Integrated Marketing Communication Prespective, $6^{\text {th }}$ Edition, McGraw Hill, New York

Ernestina M, 2008, Improving antioxidant activity and nutritional component of Philippine salt-fermented shrimp paste through prolonged fermentation, Food Chemistry $111: 72$ - 77

Sharif, 2008, Toxicological Evaluation of Some Malaysian locally processed raw food product, Food and Chemical Toxicology, 46, 368-374.

Magnadi RH, 2011, Peran Perguruan Tinggi dalam Membangun "City Branding” yang berkelanjutan : Sebuah Upaya untuk Mendorong Pertumbuhan Perekonomian Daerah", Proceeding-Social, Ekonomi, dan Humaniora, Vol. 2, No. 1 p. 281-290

Kotler, Philip dan Armstrong, 2003, Dasar-dasar Pemasaran, Jilid 1, Edisi Kesembilan, PT. Indeks Gramedia, Jakarta

Holbrook, M.B., 2000, The Millennial Consumer in the Texts of Our Times: Experience and Entertaiment. Journal of Macromarketing, 20, 178-192 